\title{
Risk factors associated with the transmission of Brazilian spotted fever in the Piracicaba river basin, State of São Paulo, Brazil
}

\author{
Celso Eduardo de Souza ${ }^{[1],[2]}$, Adriano Pinter ${ }^{[3]}$ and Maria Rita Donalisio ${ }^{[2]}$
}

[1]. Laboratório de Carrapatos, Superintendência de Controle de Endemias, Mogi Guaçu, SP. [2]. Departamento de Saúde Coletiva, Faculdade de Ciências Médicas, Universidade de Campinas, Campinas, SP. [3]. Coordenação dos Laboratórios de Referência e Desenvolvimento Científico, Superintendência de Controle de Endemias, São Paulo, SP.

\begin{abstract}
Introduction: Brazilian spotted fever (BSF) is a disease transmitted by ticks for which the etiological agent is Rickettsia rickettsii. The present essay evaluates the risk factors associated with the transmission of cases of BSF in the time period between 2003 and 2013 in the Piracicaba river basin, state of São Paulo. Methods: This essay presents a retrospective study to identify the factors associated with the transmission of cases of BSF among all suspected cases identified by the System for Epidemiological Surveillance of São Paulo (CVE). After the description of temporal distribution (onset of symptoms) and the environmental and demographic variations of the confirmed and discarded cases, a multiple logistic regression model was applied. Results: We searched 569 probable locations of infection (PLI) with 210 (37\%) confirmed cases of BSF and 359 (63\%) discarded cases. The associated variables for the confirmation of BSF in the multiple logistic model using a confidence interval (CI) of 95\% were age $(\mathrm{OR}=1.025 \mathrm{CI}: 1.015-1.035)$, the presence of Amblyomma sculptum in the environment (OR =1.629 CI: 1.097-2.439), the collection of ticks from horses $(\mathrm{OR}=1.939 \mathrm{CI}$ : 0.999-3.764), the presence of capybaras $(\mathrm{OR}=1.467 \mathrm{CI}: 1.009-2.138)$, an urban environment $(\mathrm{OR}=1.515 \mathrm{CI}: 1.036-2.231)$, and the existence of a dirty pasture (OR=1.759 CI: 1.028-3.003). Conclusions: The factors associated with the confirmation of BSF cases included an urban environment, age, presence of the A. sculptum vector, the collection of ticks from horses, the presence of a capybara population, and a dirty pasture environment.
\end{abstract}

Keywords: Brazilian spotted fever. Rickettsia rickettsii. Epidemiology. Epidemiological surveillance.

\section{INTRODUCTION}

Brazilian spotted fever (BSF) is a disease transmitted by ticks for which the etiological agent is Rickettsia rickettsii, a strictly intracellular gram-negative bacteria. On the American continent, this disease has been reported in various countries and has become a relevant public health problem ${ }^{(1)}$ (2) BSF is a unique rickettsial disease that has been reported in Brazil since $2001^{(3)}$. An increase in the number of notified cases, the expansion of potential transmission area, and an elevated lethality rate have been observed in this country since the 1980s. In particular, the lethality rate in the southeast region of Brazil ranges between 30 and 50\%, with the States of São Paulo and Minas Gerais showing the most reported cases $^{(4)(5)}$.

Between 1998 and 2013, 519 cases were confirmed in State of São Paulo, out of which $80 \%$ (415) of cases were notified

Address to: Dr. Celso Eduardo de Souza. Laboratório de Carrapatos/SUCEN. Rua Afonso Pessini 86, Pedregulhal, 13845-206 Mogi Guaçu, SP, Brasil.

Phone: 55 19 9-8278-2273

e-mail: celsoesouza@gmail.com

Received 18 November 2014

Accepted 23 February 2015 in 31 municipalities of the Campinas region, which contains 90 municipalities with 6,218,275 inhabitants. Since 1985, BSF has occurred in endemic form in the Piracicaba River Basin, the region with the highest incidence of the disease in the state, although the spatial distribution is not homogeneous within this area ${ }^{(4)}$ (Figure 1).

Following diagnostic and epidemiological surveillance standardization, the disease was identified in many municipalities in the Campinas region. The results showed that the number of cases and the lethality rate increased during the period from 2007 to 2012. This increased lethality of BSF may be associated with improvements in diagnostic capacity and the investigation of deaths and the infrequent notification of mild $\operatorname{cases}^{(6)}$.

Amblyomma sculptum is a species recognized today in Brazil as part of the Amblyomma cajennense complex, as a vector that maintains circulation of $R$. rickettsii in humans. This vector is distributed throughout most of the Americas, from the wetlands of northern Argentina to the contiguous regions of Bolivia and Paraguay and the coastal states and central-west Brazili(7)(8).

Amblyomma sculptum ticks are strictly hematophagous and become infected by biting wild animals during the ricketsemia period. Transovarian transmission and transstadial perpetuation among ticks retains the disease in nature. Capybaras and horses serve as the main primary hosts for these ticks ${ }^{(9)}$. Several factors 


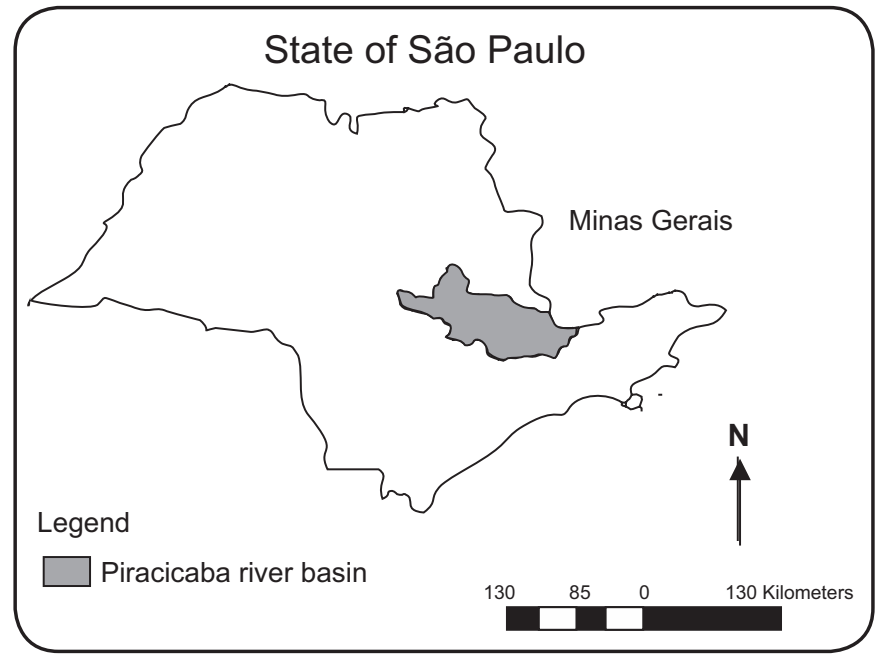

FIGURE 1 - Location of the study region in the State of São Paulo, Brazil.

may be involved in the emergence and re-emergence of BSF due to special environmental disturbances in the biome ${ }^{(10)}$. A higher risk of rickettsia transmission is observed in grassland areas and ciliary rain forests, with proximity to water resources and with the presence of mammals such as horses and capybara, in the State of São Paulo(11).

Few studies have analyzed the risk factors associated with BSF and the vectors involved in transmission in Brazil and elsewhere. However, the environmental context was shown to affect the presence of hosts and nymphs and adults forms of Amblyomma at the forest edges, and factors such as occupational activities, leisure, and age have also been identified as risk factors for $\mathrm{BSF}^{(5)(10)(12)(13)}$.

The goal of this study was to analyze the socio-demographic, epidemiological and environmental variables associated with the transmission of BSF in regions of high disease activity in the State of São Paulo and the Piracicaba River Basin in the period between 2003 and 2013.

\section{METHODS}

This retrospective study sought to identify factors associated with the transmission of BSF among suspected cases notified by the Information System for Notifiable Diseases [Sistema de Informação de Agravos de Notificação (SINAN)] in the time period from 2003 to 2013. The probable locations of infection (PLI) was investigated by the Superintendence for Endemic Disease Control [Superintendência de Controle de Endemias (SUCEN)] field team to describe the environmental characteristics of the suspected points of transmission.

The study area was the Piracicaba river basin, which crosses the region of Campinas in the State of São Paulo. This region comprises 65 municipalities and 4 cities of Minas Gerais. Figure 1 shows that the total area extends $370 \mathrm{~km}$, with a range of $15.303,67 \mathrm{~km}^{2}$, and includes the basins of the Capivari, Jundiaí and Piracicaba rivers (PCJ) ${ }^{(14)}$.

\section{Definition of confirmed cases}

Confirmed cases of BSF followed the criteria of the Ministry of Health. Briefly, these criteria included patients who presented the primary signals and symptoms of BSF (fever, headache, myalgia, exanthema and/or bleeding manifestation) and epidemiological antecedents associated with the following laboratory criteria: isolation of etiological agent in culture or serology in two samples taken within a range of 15 days; seroconversion of 4 times the baseline titer; and positive immune-biochemistry for Rickettsia spp $^{(15)}$.

All BSF notifications were reviewed to separate the confirmed and discarded cases from all of the cases investigated by the epidemiological surveillance field team.

\section{Data source and study variables}

Variables such as sex, age, and date of onset of symptoms were obtained from the SINAN at the Ministry of Health. The geographic coordinates $(\mathrm{X}, \mathrm{Y})$ and environmental variables, such as pasture cleanliness, presence of riparian forest, degree of reforestation, hydrographics, and information about the presence of hosts and vectors (Amblyomma ssp., capybaras, horses, and dogs), were obtained from the field epidemiological investigation records made by the SUCEN teams during the study time period.

Field investigations consisted of visits to BSF-suspected patients to identify the possible locations where they were parasitized by ticks. All confirmed cases and approximately $50 \%$ of the most likely of suspected cases were visited by the field team. After confirmation of the existence of a transmission area, the area was not visited again. Environmental information was collected during the field investigation, including factors such as the presence of rural or urban/peri-urban environment, use and occupation of land, and the presence of vectors and hosts. The ticks were captured using dry ice traps and the dragging of flannel through vegetation, and the species were identified using taxonomic keys $^{(16)(17)(18)}$. Ticks were also collected from horses, dogs, and from the garb of professional field investigators (captors). The geographic coordinates were recorded at the collection points for ticks and at the locations of capybaras via GPS (Global Positioning System) using the WGS84 South Hemisphere as a reference system.

\section{Statistical analysis}

After describing the temporal distribution (onset of symptoms) and environmental and demographic variables of confirmed cases and discarded groups, a multiple logistic regression model was adopted using the confirmed cases of BSF as dependent variables (case confirmed $=1$ and discarded $=0$ ) and the independent variables described above. The variables with a $p$-value $\leq 0.25$ in the univariate analysis were included in the model. In the final multiple model, variables with estimates of association with $p$-values $\leq 0.05$ via stepwise regression were included. The odds ratios (OR) and confidence intervals $(95 \%, \mathrm{CI})$ were estimated. Analyses were performed using R software, version 2.15.1, and graphics of temporal trend (incidence and mortality) were built using the Excel program v 10.0.

\section{Ethical considerations}

This investigation was approved by the Research Ethics Committee of the Faculty of Medical Sciences, Unicamp (process: 1192/2011). 


\section{RESULTS}

A total of 569 PLI were investigated with $210(37 \%)$ confirmed cases of BSF and $359(63 \%)$ discarded cases. The frequency distribution of each study variable and the number of individuals of the species of hosts and vectors are described in Table 1. More than one environment was studied in the PLI investigation of one case.

We found a predominance of cases among men $(73.8 \%)$ and in the age group spanning 20-49 years (46.6\%). The mean age of BSF cases was 27 years, ranging from 1-80 years. The incidence was higher in urban/peri-urban environments (69.1\%) and in areas with riparian vegetation $(44.4 \%)$. The presence of dogs, horses, and capybaras was recorded for both BSF and discarded cases.

There was a seasonal pattern to BSF disease, with more cases confirmed between August and November. The monthly distribution of confirmed and discarded cases was similar, as shown in Figure 2.

According to multiple logistic regression analysis, the variables associated with BSF transmission included age $(\mathrm{OR}=1.03 \mathrm{CI}: 1.02-1.04)$, the presence of $A$. sculptum ticks in the environment $(\mathrm{OR}=1.63 \mathrm{CI}$ : $1.10-2.44)$, ticks collected from horses $(\mathrm{OR}=1.94 \mathrm{CI}: 0.99-3.76)$, the presence of capybaras $(\mathrm{OR}=1.47 \mathrm{CI}: 1.01-2.14)$, an urban/peri-urban environment $(\mathrm{OR}=1.52 \mathrm{CI}: 1.04-2.23)$, and the existence of a dirty pasture environment ( $\mathrm{OR}=1.76 \mathrm{CI}$ : 1.03-3.01) (Table 2).

\section{DIscussion}

The results of this study suggest that BSF transmission is linked to age and environmental variables such as urban/periurban areas, the existence of a dirty pasture environment, the presence of the A. sculptum vector, ticks collected from horses, and the presence of capybaras around PLI.

The risk of BSF disease increases with age, mostly affecting patients older than 10 years and young adults. The occurrence of disease in these age groups, particularly among men, as a result of leisure or work in peri-urban areas and basin regions has been described by several authors ${ }^{(5)(19)(20)}$. The average age of 27.4 years found in our study was similar to that described in Minas Gerais (26.5 years) among cases reported from 2000 to $2008^{(20)}$. A study in sub-Saharan Africa reported a higher seropositivity to Rickettsia africae in individuals aged 36-45 years, which was linked to behavior or occupational exposures and leisure activities ${ }^{(12)}$.

TABLE 1 - Distribution and frequency of the variables investigated in PLI cases of BSF in the Piracicaba river basin in the period from 2003-2013.

\begin{tabular}{|c|c|c|c|c|}
\hline Variables & $\begin{array}{l}\text { Confirmed } \\
(\mathrm{n}=210)\end{array}$ & $\begin{array}{c}\text { Frequency } \\
(\%)\end{array}$ & $\begin{array}{c}\text { Discarded } \\
(\mathrm{n}=359)\end{array}$ & $\begin{array}{c}\text { Frequency } \\
(\%)\end{array}$ \\
\hline \multicolumn{5}{|l|}{ Gender } \\
\hline female & 55 & 26.2 & 116 & 32.3 \\
\hline total & 210 & 100.0 & 359 & 100,0 \\
\hline $0-9$ & 30 & 14.3 & 92 & 25.6 \\
\hline $10-19$ & 30 & 14.3 & 61 & 16.1 \\
\hline $20-29$ & 24 & 11.4 & 66 & 18.4 \\
\hline $60-69$ & 19 & 9.1 & 11 & 3.1 \\
\hline$\geq 70$ & 3 & 1.4 & 5 & 1.4 \\
\hline Total & 210 & 100.0 & 359 & 100,0 \\
\hline \multicolumn{5}{|l|}{ Urbanization } \\
\hline urban/peri-urban & 145 & 69.1 & 224 & 62.4 \\
\hline rural & 65 & 30.1 & 135 & 37.6 \\
\hline Total & 210 & & 359 & \\
\hline
\end{tabular}


TABLE 1 - Continuation.

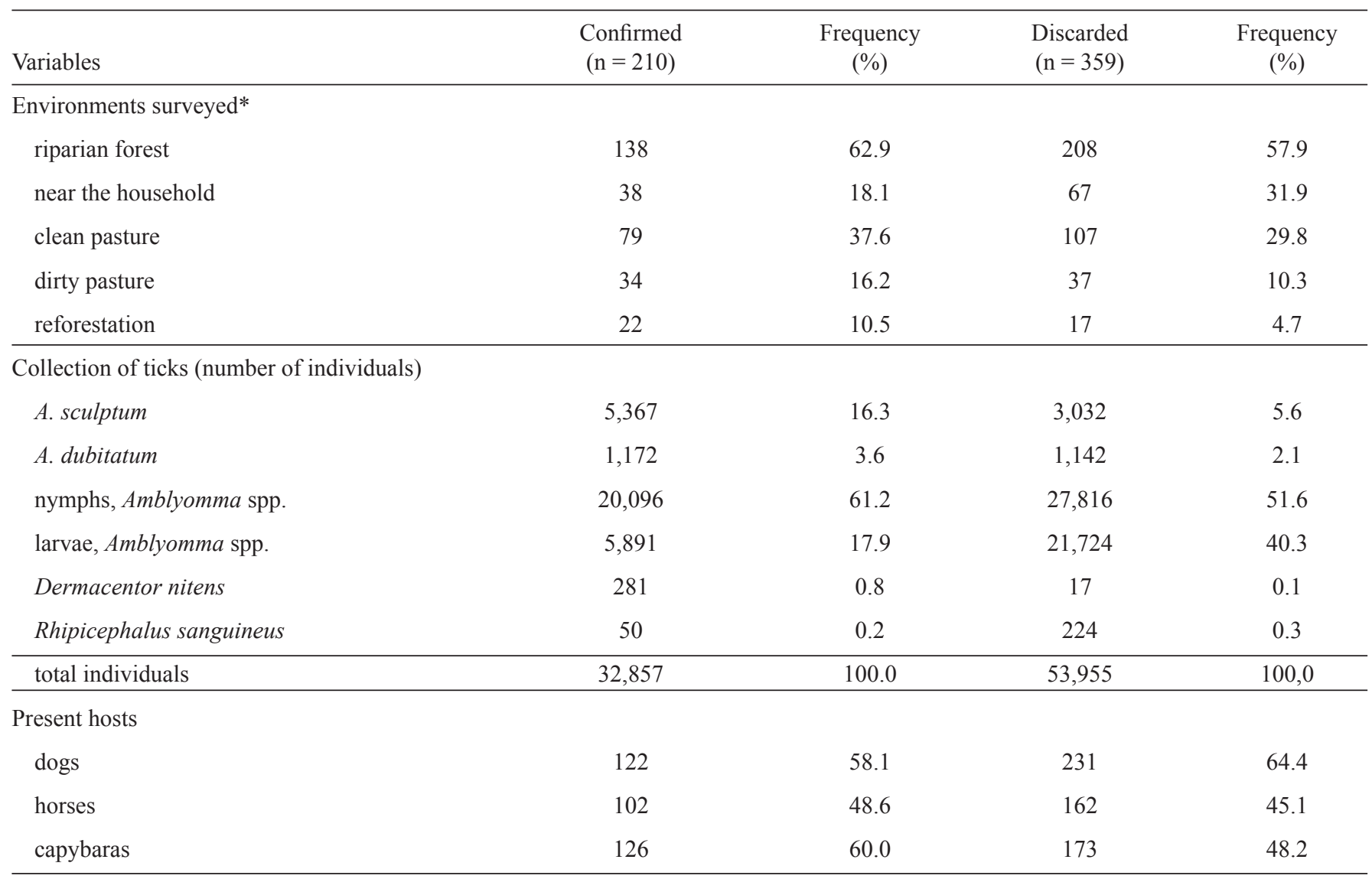

A.: Amblyoma; PLI: probable locations of infection BSF: Brazilian spotted fever *More than one environment was studied in a PLI investigation of one case.

Environmental factors such as climate, vegetation and land use are part of the natural focus of BSF. As suggested by Pavlovsky in $1939^{(21)}$, the natural outbreak of disease relates to a specific landscape characterized by defined biotopes favorable to wild cycles of zoonoses ${ }^{(21)}$.

The seasonality of the confirmed cases was evident from August to November, coinciding with the immature stages of the tick, which show lower parasitic specificity for hosts ${ }^{(5)}$. Furthermore, the unconfirmed suspected cases presented the largest increase from August to November, confirming a similarity among suspicion and notification. In this study, the location of PLI was common in urban and peri-urban (62.4\%) regions. Areas are classified as urban or peri-urban areas if they are inhabited lands in the suburbs of towns that are located near river banks or urban public parks with tall vegetation and signs of degradation. The occurrence of disease in urban/peri-urban areas has implications for disease control, particularly focusing on prevention.

The presence of Amblyomma sculptum during the investigation of PLI and the identification of horses infested by this species of tick indicates high vector infestation in areas where cases have been confirmed. Large infestations were also recorded in São Paulo and Minas Gerais ${ }^{(16)(22)}$.

Horses have been considered an important link in the movement of rickettsias because they are the primary hosts for Amblyoma sculptum and serve as sentinels of human cases $^{(22)}{ }^{(23)}$. Primary hosts are essential for the amplification and maintenance of ticks in the environment; without these hosts, the tick cycle is impeded, and its abundance is reduced.

Although not susceptible to infection, equines provide a host for tick maturation and serve as sentinels in animal serum epidemiological studies, showing the distribution of the disease and predicting human cases ${ }^{(23)}$.

In this study, the presence of dirty pastures and riparian forests reinforces the relevance of these environments as favorable to BSF because they concentrate the vectors and enable amplification of $R$. rickettsi $i^{(24)}$. Humans enter this environment as accidental hosts of the infectious agent.

An increase in infestation of mammals by infected ticks leads to a transmission risk of BSF to humans ${ }^{(3)(6)}$. This transmission is a consequence of ecosystem degradation, resulting from irregular occupation, agriculture and livestock advance in natural areas, as well as an increase in capybara (Hydrochoerus hydrochaeris) due to lack of natural predators ${ }^{(10)(13)(25)}$.

Until the mid of XX century, BSF was typically described in rural regions in Brazil, similarly to other parts of the world ${ }^{1}$. However, since the 1990s, BSF transmitted by A. sculptum has spread to urban and peri-urban areas as well ${ }^{(11)}$. 


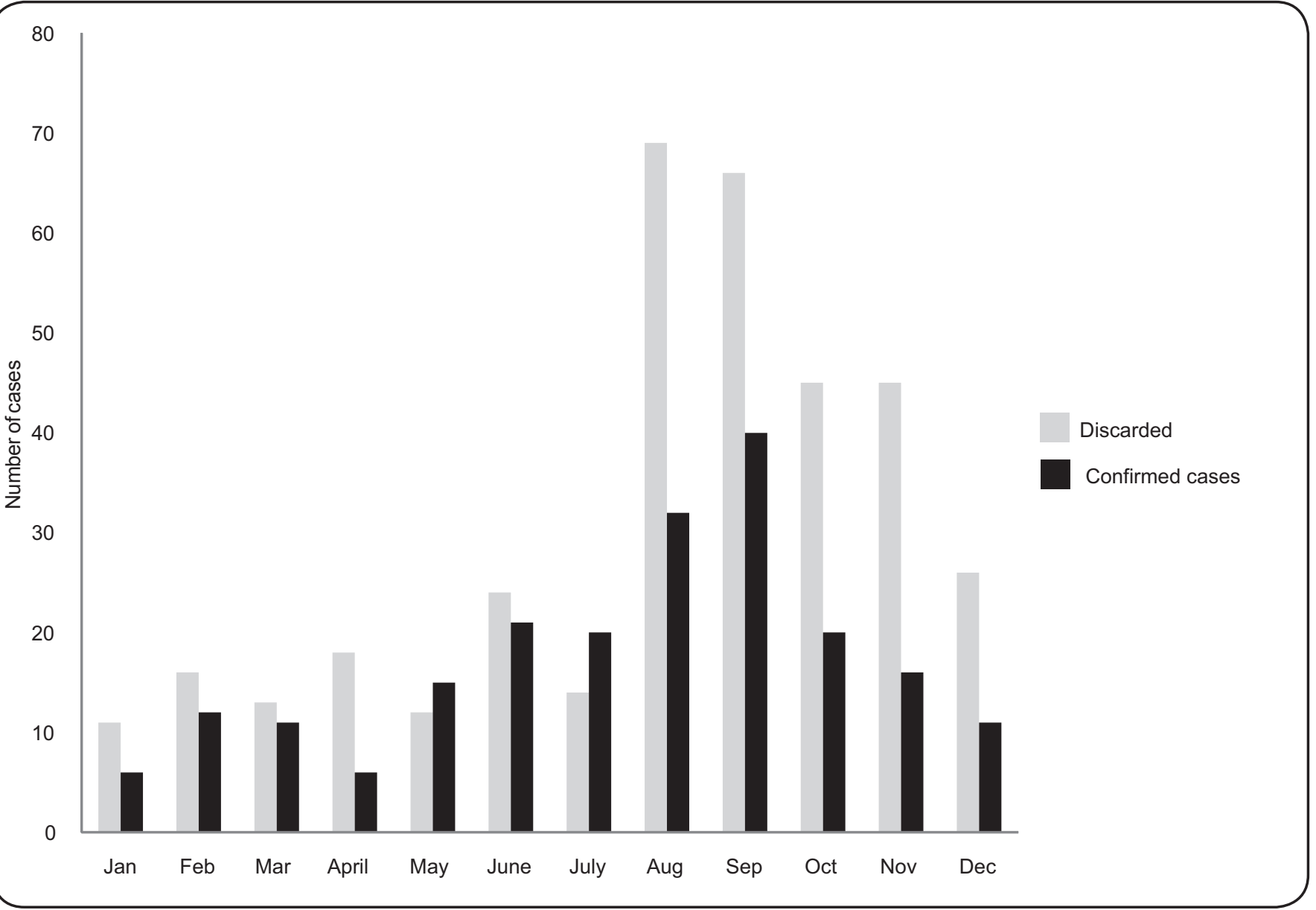

FIGURE 2- Monthly distribution of the onset of symptoms of confirmed and discarded cases of BSF in the Piracicaba river basin, São Paulo, from 2003 to 2013. BSF: Brazilian spotted fever.

In the present study, the presence and abundance of A. sculptum were strongly associated with areas of medium and dense vegetation cover, such as dirty pastures, barns and riparian forests. In the region of Campinas, the presence of riparian forest is likely the cause for increased A. sculptum vector frequency and transmission of BSF, as this ecosystem hosts large populations of capybaras ${ }^{(26)}$.

Ecological factors have been associated with higher seropositivity for spotted fever in African villages in rural areas, demonstrating that wetter forest areas are at higher risk of transmission of $\mathrm{BSF}^{(12)}$.

Another factor associated with disease transmission in the Piracicaba River Basin was the presence of capybaras in PLI. The tick vector species $A$. sculptum employs the capybara as the main amplifier host of $R$. rickettsii in the region. In São Paulo, especially in the area of our study, the ecological scene has undergone change since the 1980 s, following government incentives for the production of alcohol for fuel, involving increased cultivation of sugar cane and the destruction of riparian forests. During this period, laws for wildlife protection also prohibited hunting in the State of São Paulo. The combination of these two factors favored an increased population of capybaras, a primary host for A. sculptum.

Although the capybara is not a reservoir of $R$. rickettsii, it serves as an excellent host amplifier and is a disseminator of the bacteria, which can infect $30 \%$ of the ticks that feed on capybaras during the period of rickettsemia ${ }^{(24)}$.

Rickettsia rickettsii was recently isolated in Amblyomma sculptum ticks collected in capybaras in a residential condominium in an endemic area of São Paulo, thus confirming the aforementioned assumptions ${ }^{(27)}$. The association of confirmed cases in the presence of capybaras in this study is consistent because the investigation of all suspected cases of BSF occurred in situations with clinical evidence and an epidemiological history of disease, including contact with hazardous environments and the presence of host species. The identification of discarded cases, therefore, represents a limitation of this study and may have contributed to misclassification between cases and controls, as it is possible that false negative cases were enrolled in the control group. Thus, estimators of chance of BSF confirmation 
TABLE 2 - Results of univariate logistic regression models analyzing demographic, vector, host, and environmental variables associated with BSF in the Piracicaba river basin, São Paulo, Brazil from 2003-2013.

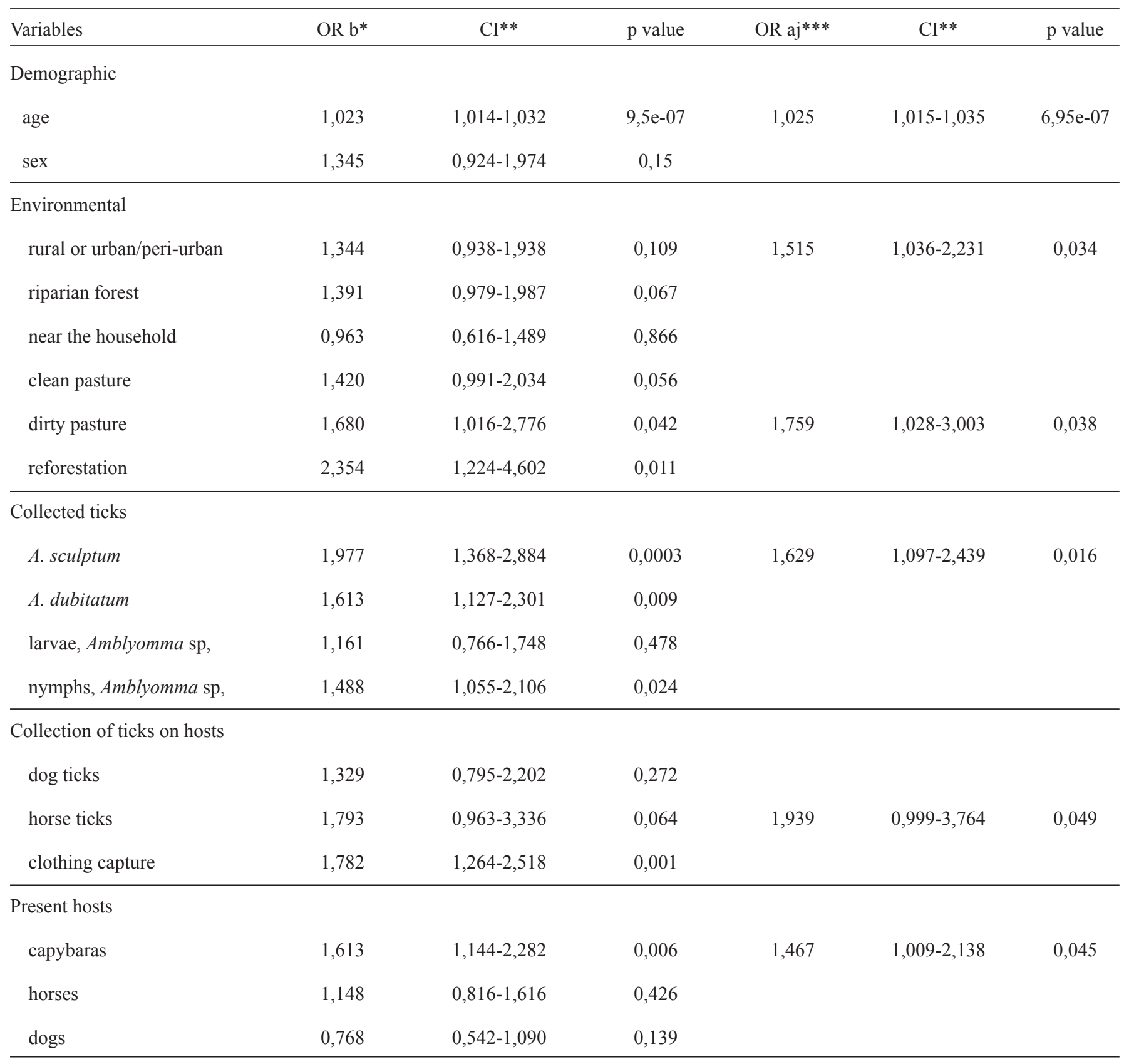

A.: Amblyoma; BSF: Brazilian spotted fever; *OR b: odds ratio gross; **CI: confidence interval; ***OR ajs: odds ratio adjusted.

(OR) may have been biased towards the null hypothesis, i.e., no association. Nonetheless, the association persisted in the final model. In addition, some cases of BSF may have been discarded and undiagnosed due to lack of timely collection of biological materials. Classification bias may also have driven our estimations towards the null hypothesis. Nevertheless, the variables that remained statistically significant in the final multiple logistic model serve as predictors of transmission.
In short, the confirmed cases of BSF in high-incidence areas in the State of São Paulo reinforce the trend of urbanization of this disease in degraded peri-urban peripheries. The presence of ticks and capybaras during the investigation was remarkable and should be valued in future field investigations. Control measures focusing on the elimination of dirty pastures and the prevention of human contact with areas of host and vector species should be employed to control the transmission of BSF. 


\section{CONFLICT OF INTEREST}

The authors declare that there is no conflict of interest.

\section{FINANCIAL SUPPORT}

Conselho Nacional de Desenvolvimento Cientifico e Tecnológico (CNPq).

\section{REFERENCES}

1. Dumler JS, Walker DH. Rocky mountain spotted fever changing ecology and persisting virulence. New England J Med 2005; 353:551-553.

2. Paddock CD, Fernandez S, Echenique GA, Sumner JW, Reeves WK, Zaki SR, et al. Rocky Mountain spotted fever in Argentina. Am J Trop Med Hyg 2008; 78:687-692.

3. Ministério da Saúde. Doenças Infecciosas e Parasitárias: Guia de Bolso. $8^{\text {th }}$ ed. Brasília/DF: Ministério da Saúde; 2010. p. 184.

4. Lima VLC, Souza SSL, Souza CE, Vilela MFG, Papaiordanou PMO, Del Guércio VMF, et al. Situação da febre maculosa na região Administrativa de Campinas, São Paulo, Brasil. Cad Saude Publica 2003; 19:331-334.

5. Katz G, Camargo-Neves VLF, Angerami RN, Nascimento EMM, Colombo S. Situação epidemiológica e importância da febre maculosa no estado de São Paulo. Bol Epidemiol Paul 2009; 6:4-13.

6. Angerami RN, Silva MV, Santos FCP, França AC. Febre maculosa brasileira: aspectos clínicos epidemiológicos, diagnósticos e terapêuticos. In:: Meira AM, Cooper M, Ferraz KMPMB. (Org.). Febre Maculosa: Dinâmica da Doença, hospedeiros e vetores. $1^{\text {st }}$ ed. Piracicaba: Serviços de Produções Gráficas (ESALQ/USP); 2013. p. 32-51.

7. Dias E, Martins AV. Spotted fever in Brazil. A summary. Am J Trop Med Hyg 1939; 19:103-108.

8. Beati L, Nava S, Bukman EJ, Barros-Battesti DM, Labruna MB, Guglielmone AA, et al. Amblyomma cajennense (Fabricius, 1787) (Acari: Ixodidae), the cayenne tick: phylogeography and evidence for allopatric speciation. BMC Evol Bio 2013; 13:267.

9. Monteiro JL, Fonseca F. Typho exantemático de S. Paulo. XI. Novas experiências sobre a transmissão experimental por carrapatos (Boophilus microplus e Amblyomma cajennense). Mem Inst Butantan 1932; 7:35-40.

10. Stein JK, Waterman M, Waldon JL. The effects of vegetation density and habitat disturbance on the spatial distribution of ixodid ticks (Acari: Ixodidae). Geospatial Health 2008; 2:241-252.

11. Secretaria do Estado da Saúde São Paulo. Centro de controle de Doenças. Febre Maculosa Brasileira. Bol Epidemiol Paul 2011; 8 (suppl I). [Cited 2014 February 20]. Available at: http://www. saude.sp.gov.br/resources/sucen/homepage/downloads/arquivosde-febre-maculosa/bepa94_suplemento_fmb.pdf.

12. Ndip LM, Biswas HH, Nfonsam EL, LeBreton M, Ndip RN, Bissong MA, et al. Risk Factors for African Tick-Bite Fever in Rural Central Africa. Am J Trop Med Hyg 2011; 84:608-613.
13. Ogrzewalska M, Saraiva DG, Moraes-Filho J, Martins TF, Costa FB, Pinter A, et al. Epidemiology of Brazilian spotted fever in the Atlantic Forest, state of São Paulo, Brazil. Parasitol 2012; 139:1283-1300.

14. Engenharia e Consultoria em Recursos Hídricos e Meio Ambiente Ltda. Caracterização das Bacias do PCJ. [Cited 2014 February 20]. Available at: http://www.agenciapcj.org.br /novo/images/stories/ Relatorio_de_situacao/rs-2004-2006/RS-04-06_Capitulo-2.pdf.

15. Sistema de Informação de Agravos de Notificação (SINAN). Secretaria de Vigilância à Saúde. Normas e Rotinas. Brasília: Ministério da Saúde; 2002.

16. Oliveira PR, Borges LM, Leite RC, Freitas CM. Seasonal dynamics of the Cayenne tick, Amblyomma cajennense on horses in Brazil. Med Vet Entomol 2003; 17:412-416.

17. Aragão HB, Fonseca F, Notas de Ixodologia. VII. Lista e chave para os representantes da fauna ixodológica brasileira. Mem Inst Oswaldo Cruz 1961; 59:115-130.

18. Barros-Battesti DM, Arzua M, Bechara GH. Carrapatos de Importância Médico - Veterinária da Região Neotropical - Um guia ilustrado para identificação de espécies. São Paulo: Vox/ ICTTD-3/Butantan; 2006.

19. Angerami RN, Resende MR, Feltrin AFC, Katz G, Nascimento EM, Stucchl RSB, et al. Brazilian Spotted Fever: A Case Series from an Endemic Area in Southeastern Brazil - Epidemiological Aspects. Ann NY Acad Sci 2006b; 1078:170-172.

20. Amâncio FF, Amorim VD, Charmone TL, Brito MG, Calic SB, Leite AC, et al. Epidemiological characteristics of Brazilian spotted fever in Minas Gerais State, Brazil, 2000-2008. Cad Saude Publica 2011; 27:1969-1976.

21. Pavlovsky EN. Natural nidality of transmisible diseases with special reference to the landscape. In: Levine ND, editor: epidemiology of zooanthroponosis. Urbana, IL: University of Illinois Press; 1966, p. 261.

22. Labruna MB, Kerber CE, Ferreira F, Faccini JLH, Waal DT, Gennari SM. Risk factors to tick infestations and their occurrence on horses in the state of São Paulo, Brazil. Vet Parasitol 2001; 97:1-14.

23. Sangioni LA, Horta MC, Vianna MCB, Gennari SM, Soares RM, Galvão MAM, et al. Ricketsial infection in animals and brazilian spotted fever endemicity. Emerg Infect Dis 2005; 11:265-269.

24. Souza CE, Moraes-Filho J, Ogrzewalska M, Uchoa FC, Souza SS, Borba RC, et al. Experimental infection of capybaras Hydrochoerus hydrochaeris by Rickettsia rickettsii and evaluation of the transmission of the infection to ticks Amblyomma cajennense. Vet Parasitol 2009; 161:116-121.

25. Ferraz KNPNV, Peterson AT, Scachetti-Pereira R, Vttoraeei CA, Verdade LM. Distribution of Capybaras in an agroecosysten, sutheasterm Brazil, based on ecological niche modeling. J Mammal 2009; 90:189-194.

26. Souza SSAL, Souza CE, Rodrigues Neto EJ, Prado AP. Dinâmica sazonal de carrapatos (Acari: Ixodidae) na mata ciliar de uma área endêmica para febre maculosa na região de Campinas, São Paulo, Brasil. Cienc Rural 2006; 36:887-891.

27. Krawczak FS, Nieri-Bastos FA, Nunes FP, Soares FJ, Moraes-Filho $\mathrm{J}$, Labruna MB. Rickettsial infection in Amblyomma cajennense ticks and capybaras (Hydrochoerus hydrochaeris) in a Brazilian spotted fever-endemic area. Paras Vectors 2014; 7:7. 